\title{
A APLICAÇÃO DO CONCEITO DE OROGENIA NO CICLO BRASILIANO COM EXEMPLOS DO RIO GRANDE DO SUL
}

\author{
A.R.S.Fragoso Cesar
}

O conceito de orogenia tem sido aplicado ao estudo da formação de cadeias de montanhas situadas nos limites convergentes de placas, particularmente em faixas orogênicas fanerozóicas onde, além da compreensão do plutonismo, vulcanismo, sedimentação, deformação e metamorfismo decorrentes, trabalhos integrados de tectônica e estratigrafia têm permitido, através da identificação das paleogeografias envolvidas, suas estruturações e separação por discordâncias regionais, a individualização das distintas orogenias responsáveis pela edificação de um dado cinturão orogênico, como exemplificado pelas orogenias Taconiana, Acadiana e Alleghaniana do Cinturão Apalachiano da costa leste da América do Norte.

A carência de estudos estratigráficos no Pré-Cambriano brasileiro, em parte devido a amplas exposições de niveis crustais profundos, tem sido tentativamente compensada pelo progressivo desenvolvimento de análises geocronológicas e estruturais, permitindo, então, uma divisão maior da evolução geológica em ciclos geotectônicos (e.g., Ciclos Brasillano e Tranєamazônico), como regra confundidos com orogenias. No escudo do Rio Grande do Sul, graças à notável preservação de sequências supracrustais, a conjunção de trabalhos estratigráficos (separação de paleogeografias, suas direções preferenciais de correntes e análise de proveniência) com estruturais, petrológicos e geocronológicos tem possibilitado individualizar diversas bacias orogênicas limitadas por discordâncias regionais e relacionadas à evolução de altos plutônicos e estruturais distintos. Em base a estes elementos, aliados ao estudo evolutivo destes altos, foi possível reconhecer que neste escudo afloram dois cinturões orogênicos justapostos, um a leste, o Cinturão Dom Feliclano, e outro a oeste que visualizamos como a extensão meridional do Cinturáo Ribeira,

Departamento de Geologia Geral, Instituto de Geociências, USP. 
ambos construídos por orogenias superpostas durante o Ciclo Brasiliano.

O Cinturão Dom Feliciano foi edificado durante este ciclo pela superposição das seguintes orogenias:

(1) a Orogenia Piratini ( $\left.885 / \sim 775 \mathrm{Ma} ; \mathrm{R}_{\mathrm{o}} \mathrm{Sr}^{87} / \mathrm{Sr}^{86} 0,7027-0,7062\right)$, com características de margem continental ativa do tipo Cordilherano, é representada por plutonitos calcialcalinos de raiz do Arco Magmático Pinheiro Machado e pelos depósitos vulcano-sedimentares da Bacia de Retro-Arco Cerro da Árvore que contêm pequenas concentrações de sulfetos de $\mathrm{Cu}, \mathrm{Fe}, \mathrm{Pb} e$ As;

(2) a Orogenia Porongos ( 650/ 620Ma; $\left.\mathrm{R}_{\mathrm{O}} \mathrm{Sr}^{87} / \mathrm{Sr}^{86}>0,709\right)$, formada pela obducção do sistema cordilherano anterior sobre a margem passiva oriental do Continente Rio de La Plata, foi acompanhada por geração de sheets leucograníticas, nappes e escamas tectônicas vergentes para NW, remobilização do embasamento continental e de sua cobertura miogeoclinal, intensa milonitização e imbricação tectônica, desenvolvimento da Antefossa Cerro Chato e de graisens e pegmatitos localmente mineralizados, sob condições variáveis de anquimetamórficas até anfibolito superior e migmatização;

(3) e a Orogenia Serra do Herval( 570/ 530 Ma; $\left.\mathrm{R}_{\mathrm{O}} \mathrm{S} r^{87} / \mathrm{S} r^{86}>0,709\right)$, do tipo tardi-colisional intracontinental, é arquitetada por múltiplas intrusões granfticas sub-alcalinas ao longo de zonas de cisalhamento sinistrais NE-SW, localmente concentrando fluorita, acompanhadas por pequenos diápiros gábricos, enxames de diques rioliticos e vulcanismo de tufos e ignimbritos, dobramentos abertos a fechados e instalação da Antefossa Arroio dos Nobres com cerca de $6 \mathrm{~km}$ de espessura de flysch \& molasse localmente mineralizados com sulfetos, particularmente cupriferos, sob condições metamórficas variáveis de ausentes a fácies xistos verdes; associam-se a este conjunto, ainda, intrusões graniticas peraluminosas mineralizadas com estanho.

Na região ocidental do escudo, a superposição das seguintes orogenias construiu a extensão meridional do Cinturão Ribeira:

(1) a Orogenia Rio Vacacai $\left(\sim 770 />650 \mathrm{Ma} ; \mathrm{R}_{\mathrm{O}} \mathrm{Sr} 87 / \mathrm{S} \mathrm{r}^{86}<0,704\right)$, um sistema de arco de lihas gerado por subducção intraoceânica com mergulho para W, é representada por ofiolitos, ortognaisses calci-alcalinos de baixa $\mathrm{K}_{2} \mathrm{O}$ da raiz do Arco Magmático Cambaí e sequências vulcano-sedimentares variáveis de tolefticas de alta $\mathrm{Al}_{2} \mathrm{O}_{3}$ a calci-alcalinas de baixa $\mathrm{K}_{2} \mathrm{O}$ contendo mineralizações diversas, particularmente aurfferas, da Bacia de Ante-Arco Vacacai;

(2) a Orogenia Vila Nova $\left(\sim 650 \mathrm{Ma}, \mathrm{R}_{\mathrm{O}} \mathrm{r}^{87} / \mathrm{S} \mathrm{r}^{86} \sim 0,704\right)$, materializada pela obducção do sistema de arco de ilhas da orogenia anterior com a margem ocidental do Continente Rio de la Plata, é acompanhada por plutonismo calci-alcalino de subducção residual, intenso nappismo 
vergente para leste concomitante à instalação da Antefossa Molássica Maricá e da Bacia de Cisalhamento Transversal Ibaré. Durante esta orogenia, em função das unidades envolvidas, as condições variavam de anquimetamórficas a facies anfibolito e migmatização;

(3) e a Orogenia Bom Jardim (<650/ 530Ma; $\mathrm{R}_{\mathrm{O}} \mathrm{Sr} \mathrm{r}^{87} / \mathrm{Sr}^{86} 0,7045-0,7077$ ), uma margem continental tipo Cordilherana distal autóctone pouco afetada por deformação e metamorfismo, é constituída por plutonismo granodiorftico-granítico com polaridade para leste coevo a vulcanismo calci-alcalino a shoshonítico do Arco Magmático Lavras do Sul e a sedimentação flysch \& molasse, contendo intercalações vulcânicas, da Bacia de Retro-Arco Santa Bárbara, possuindo diversas ocorrências minerais, particularmente $\mathrm{Au}, \mathrm{Cu}$ e $\mathrm{Pb}$.

A identificação destas orogenias, embora ainda restrita ao RS, aponta para a necessidade de estudos similares nas extensões uruguaias e brasileiras das faixas orogênicas acima discutidas para caracterizar e definir, a nível continental, os eventos orogênicos que construíram estes cinturões móveis durante o Ciclo Brasiliano. 